UNIVERSIDADE DE SÃO PAULO

ESCOLA DE COMUNICAÇÕES E ARTES

ARNALDO APARECIDO FILHO

\title{
FULIGENS
}

\section{TÍTULO: FULIGENS}

Dissertação apresentada ao Programa de Pós-Graduação em Artes, Área de Concentração: Artes Plásticas, Linha de Pesquisa: Poéticas Visuais, da Escola de Comunicações e Artes da Universidade de São Paulo, como exigência parcial para a obtenção do Título de Mestre em Artes Visuais, sob a orientação do Prof. Dr. Evandro Carlos Jardim. 
UNIVERSIDADE DE SÃO PAULO

ESCOLA DE COMUNICAÇÕES E ARTES

ARNALDO APARECIDO FILHO

\section{FULIGENS}

-Imagens construídas com fuligem de fumaça sobre conjunto de lâminas de vidro que sugere volume.

São Paulo

2009 


\section{UNIVERSIDADE DE SÃO PAULO \\ ESCOLA DE COMUNICAÇÕES E ARTES}

ARNALDO APARECIDO FILHO

\section{FULIGENS}

DUST

ABSTRACT: $\quad$-Constructed images with smoke dust on glass blades set which suggests volume.

Palavras Chave: Sfumato; Escultura; Instalação; Desenho; Fumaça; Fuligem; Vidro; Transparência; Imagens simultâneas. 


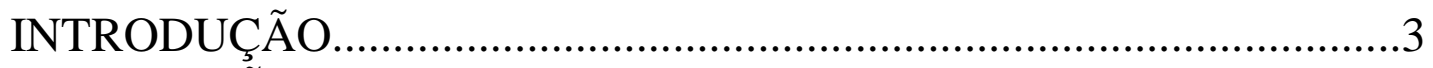

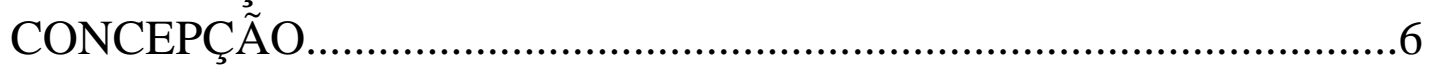

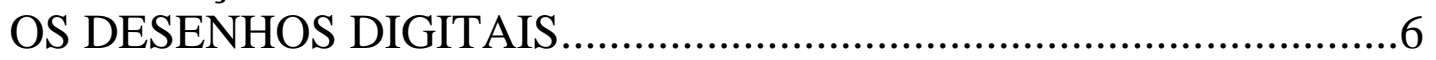

OS TRABALHOS DA DÉCADA DE 1980_........................................16

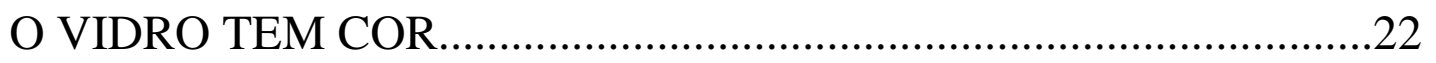

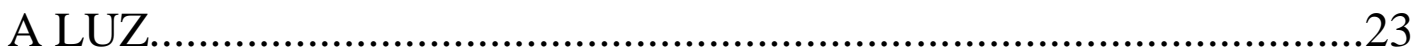

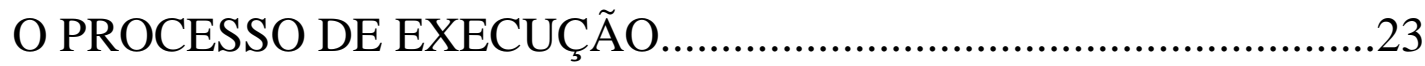

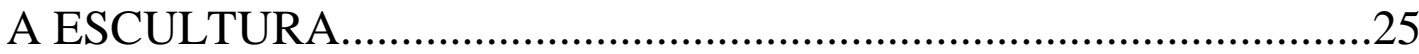

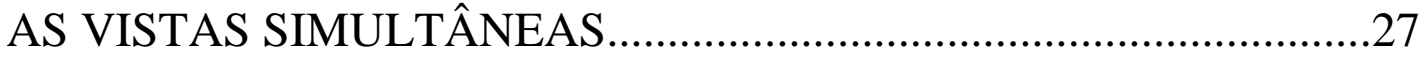

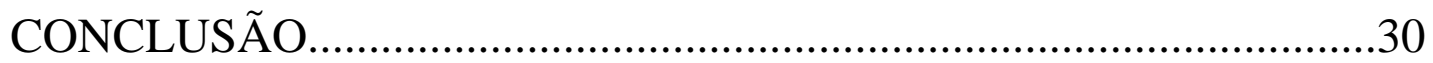

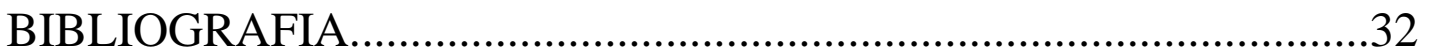




\section{FULIGENS}

\section{INTRODUÇÃO:}

Voltado para as qualidades da linguagem no âmbito do volume, o presente projeto averigua o espaço tridimensional construído com planos transparentes, grandes lâminas de vidro, com camadas de fuligem de fumaça, e os vãos entre eles.

Foram realizadas maquetes nas dimensões de $30 \times 50 \mathrm{~cm}$. de modo a sugerir a imagem figurativa estereométrica de um felino.

Essa imagem é construída por meio de camadas desenhadas com a fuligem da chama de um pavio. E os vãos entre as lâminas são ativos - corredores - porque permitem a passagem do espectador e promovem também uma experiência perceptiva de dentro da obra.

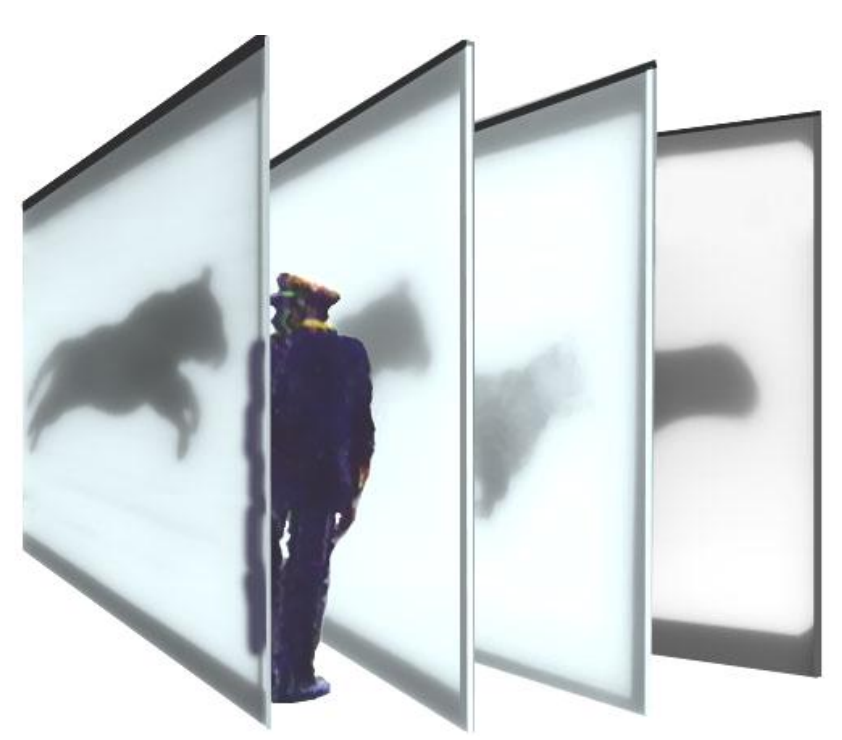




\section{FULIGENS}

Este texto surge como instrumento para procurar as origens e revelar a situação de uma obra já pronta; portanto, ele aparece como um roteiro rememorado da trajetória da produção de trabalhos anteriores que, de certo modo, deram origem à sua forma atual. O texto também surge como reflexão sobre o processo dessa produção essencialmente artesanal com um modus operandi estabelecido basicamente sobre a manipulação prática e a observação.

Não procurei temas. Os temas me procuraram. Creio que sou o melhor meio possível, isto é: não pensei em falar de labirintos, falar de armas brancas, falar de tigres, falar de espelhos, não. Esses temas insistem em que eu os escreva. São como obsessões, porém obsessões amáveis, carinhosas, e, já que voltam nos meus sonhos, na minha imaginação, voltam àquilo que se veio chamar de literatura... Ou seja, creio que o poeta é, melhor dizendo, passivo: recebe e agradece algo e, a seguir, procura informá-lo em palavras que não sejam demasiado indignas desse dom desconhecido que ele recebe continuamente ou, às vezes, de tempo em tempo.

Jorge Luis Borges in Cinco Visões Pessoais.

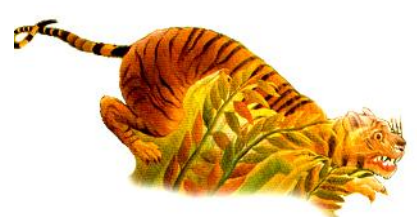

Douanier Rousseau. Surpreendido! 1891.

Óleo sobre tela, 116 x 162,5 cm. Kunstmuseum Basel. Detalhe. 


\section{CONCEPÇÃO:}

Averiguando a produção realizada no passado, notei que o projeto atual penso como esculturas de fuligem de fumaça - é na verdade, a convergência de dois caminhos traçados paralelamente. Um diz respeito aos desenhos digitais (a partir do ano 2000) - computador - e o outro está localizado na relação tradicional entre $\boldsymbol{a}$ figura e o fundo (década de 1980). Estes dois caminhos foram separados por um período de ausência de produção criativa que durou dez anos, toda a década de noventa.

A partir do ano 2000 retornei à atividade prática da arte. Reiniciei com a execução de desenhos de maneira bastante incipiente no programa Paint - o programa de desenho mais elementar da Microsoft.

\section{Os Desenhos Digitais: A COR DIGITAL E A COR IMPRESSA}

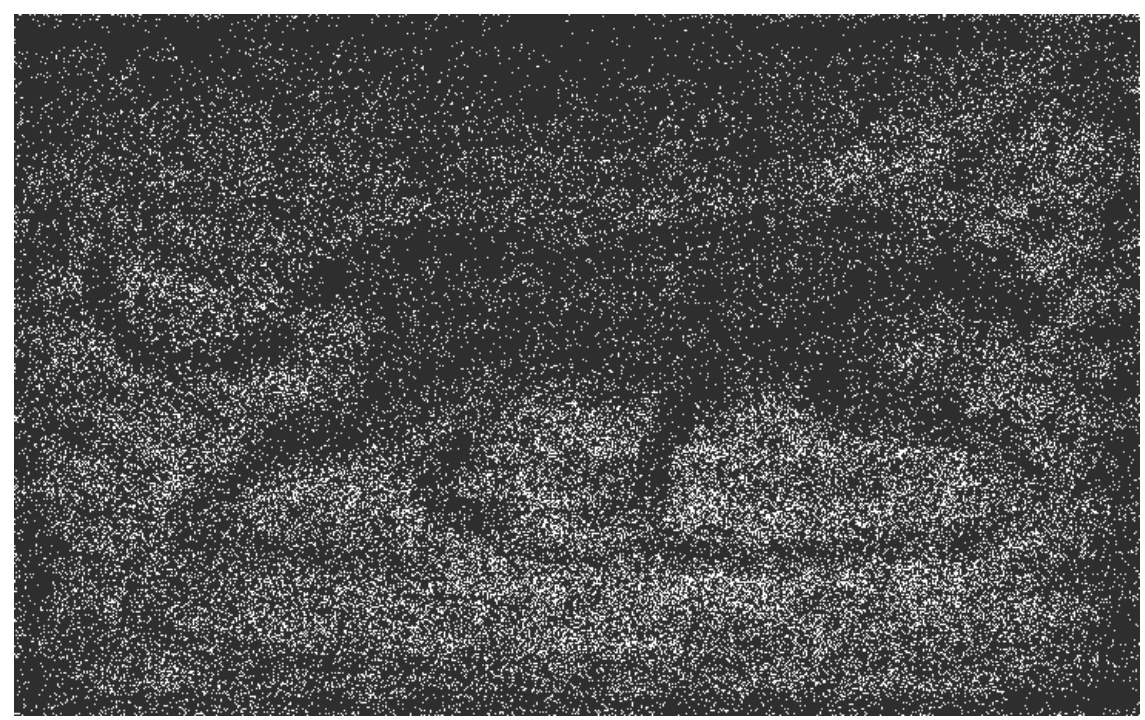

Noite 5. Desenho digital no programa Paint. Araçatuba - SP, 2000.

Eram desenhos figurativos, recolhidos da memória, sem um propósito definido, parecia que estava desenhando para tentar resgatar meramente uma prática que julgava perdida. No entanto, o que me fascinou primeiramente naquele momento foi o fato de que minha produção no meio virtual poderia ser armazenada num espaço menor que a produção anterior (esculturas) e que poderia descartar qualquer trabalho sem prejuízo material, ou seja, em ambos os casos, o aspecto das qualidades físicas sendo substituídas pelas qualidades virtuais. Aspecto esse que também pode ser notado na produção atual. 
Depois notei as propriedades de intensidade da cor-luz que o monitor projetava, mas que não ocorria quando ela era impressa: cor pigmento.

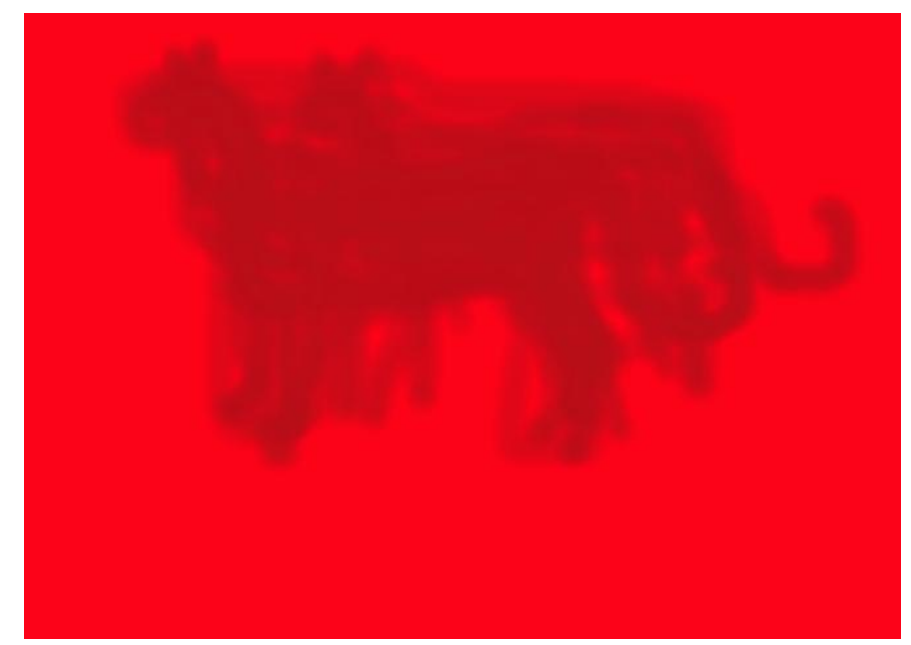

Meio Dia, mormaço. Desenho digital no programa Photoshop 5 . Araçatuba - SP, 2000.

E mais tarde, depois do domínio manual do mouse (com esfera) para a execução do desenho, me encantei com os recursos de recortar, copiar, redimensionar, alterar infinitamente o mesmo desenho. Ou seja, noções primárias para quem inicia as potencialidades de um programa básico.

Trabalhei o campo virtual como se ele ainda fosse uma folha de papel real e o mouse, um lápis.

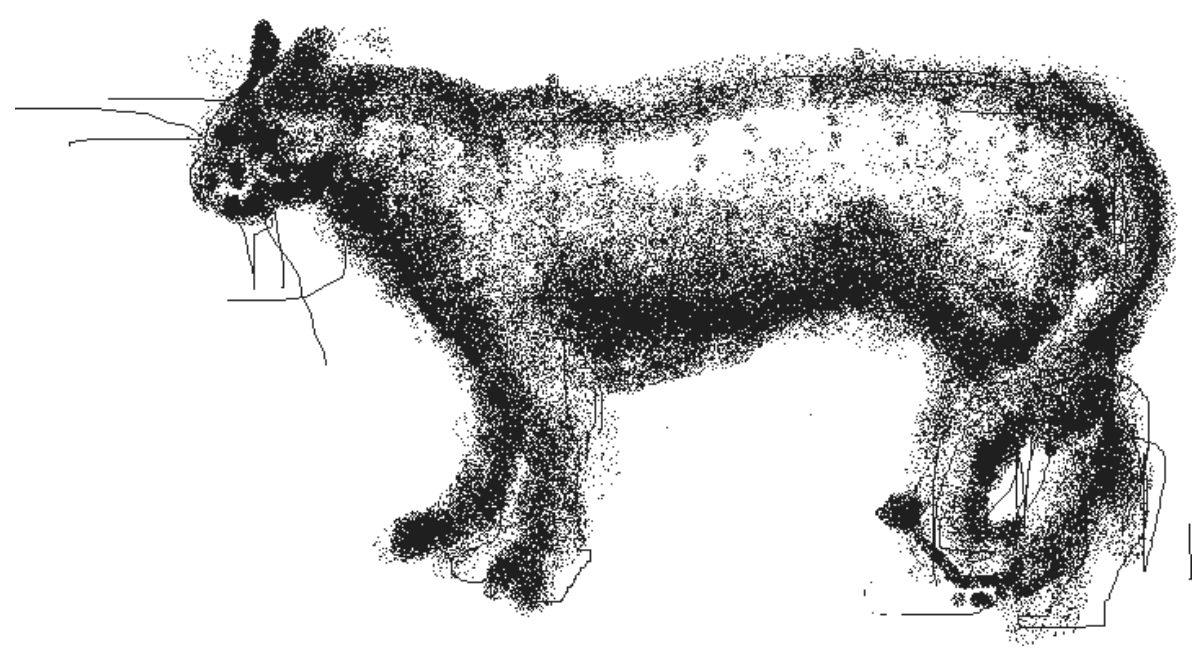

Dia 3. Desenho digital no programa Paint. Araçatuba - SP, 2000.

Olhando os trabalhos isoladamente, notava que se bastavam nos recursos básicos do desenho, porém, algumas vezes os desenhos adquiriam um tom anedótico, como em Tom and Jerry: 


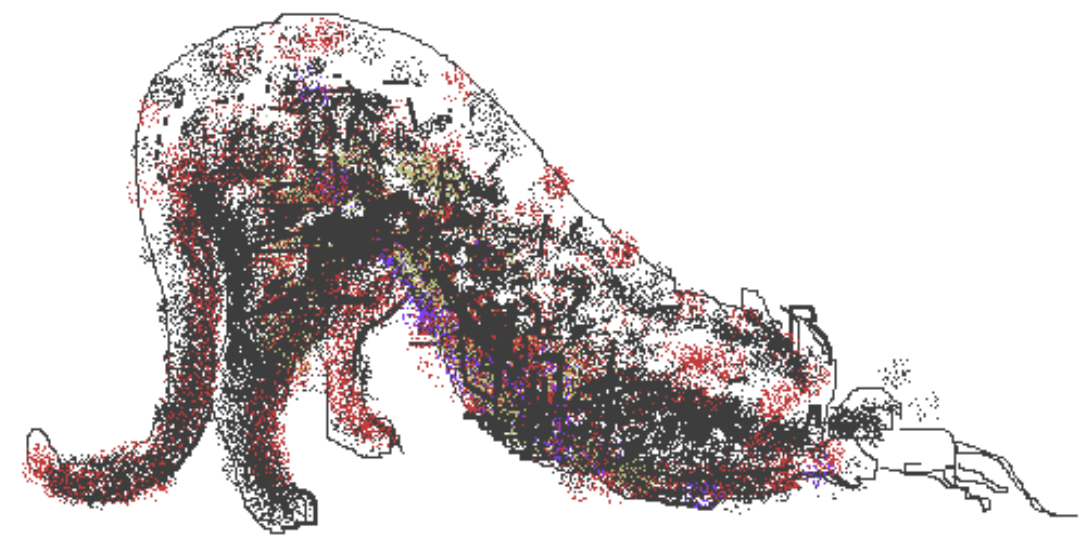

Tom and Jerry. Desenho digital no programa Paint. Araçatuba - SP, 2000.

A partir de um acúmulo de trabalhos realizados durante os meses seguintes, agora já utilizando outros programas de desenho no computador como o Photoshop, consegui agrupá-los por afinidades com a ajuda do webdesigner Amadeu Zanon. Essas afinidades não foram preestabelecidas no momento em que os trabalhos foram criados, grupos que receberam títulos como Amanhece, Dia e Anoitece, numa referência à variante luminosa empregada neles. E resolvi apresentá-los na forma de animações exibidas num projetor datashow no programa Macromedia Flash programa que permite o movimento em forma de animações: daí o entusiasmo pela representação do movimento.

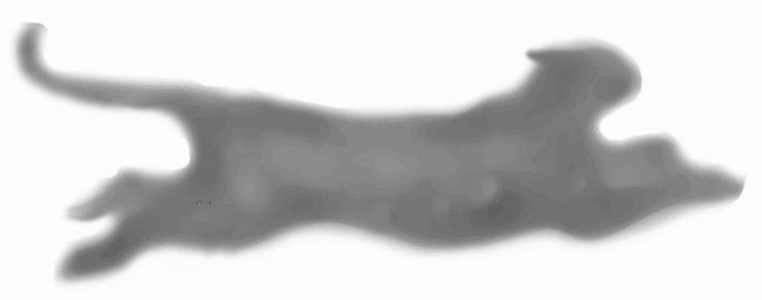

Fuga 2. Desenho digital no programa Photoshop 5. Araçatuba - SP, 2000. 
Essas animações foram projetadas numa tela de grande formato - $4 \mathrm{~m}$. x $5 \mathrm{~m}$. - o que me causou um fascínio pelo grande formato: o desenho tímido parecia ter recebido algum vigor e causava um impacto que nos trabalhos pequenos não conseguia causar, e, de certo modo, as qualidades da cor-luz haviam sido preservadas já que elas se mantiveram como cor-luz quando projetadas.

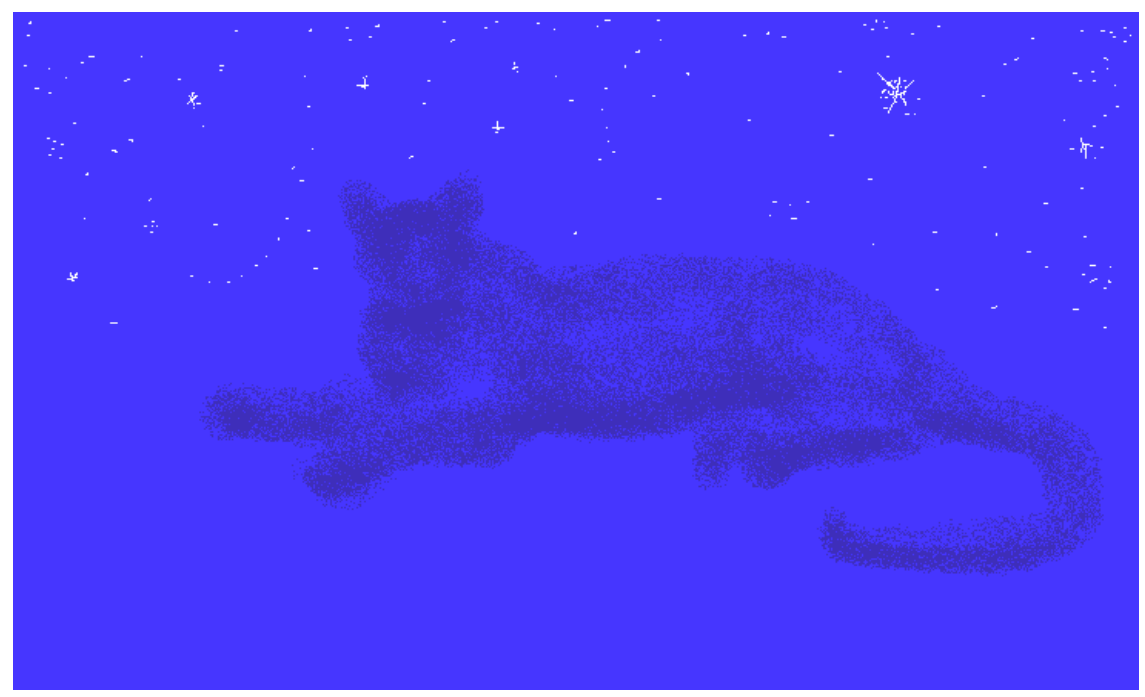

Estrelas: Noite 2. Desenho digital no programa Paint. Araçatuba - SP, 2000. 
A Seqüência 1: Fuga, a seguir, é um trecho de uma das animações em Flash realizadas no ano 2000 .
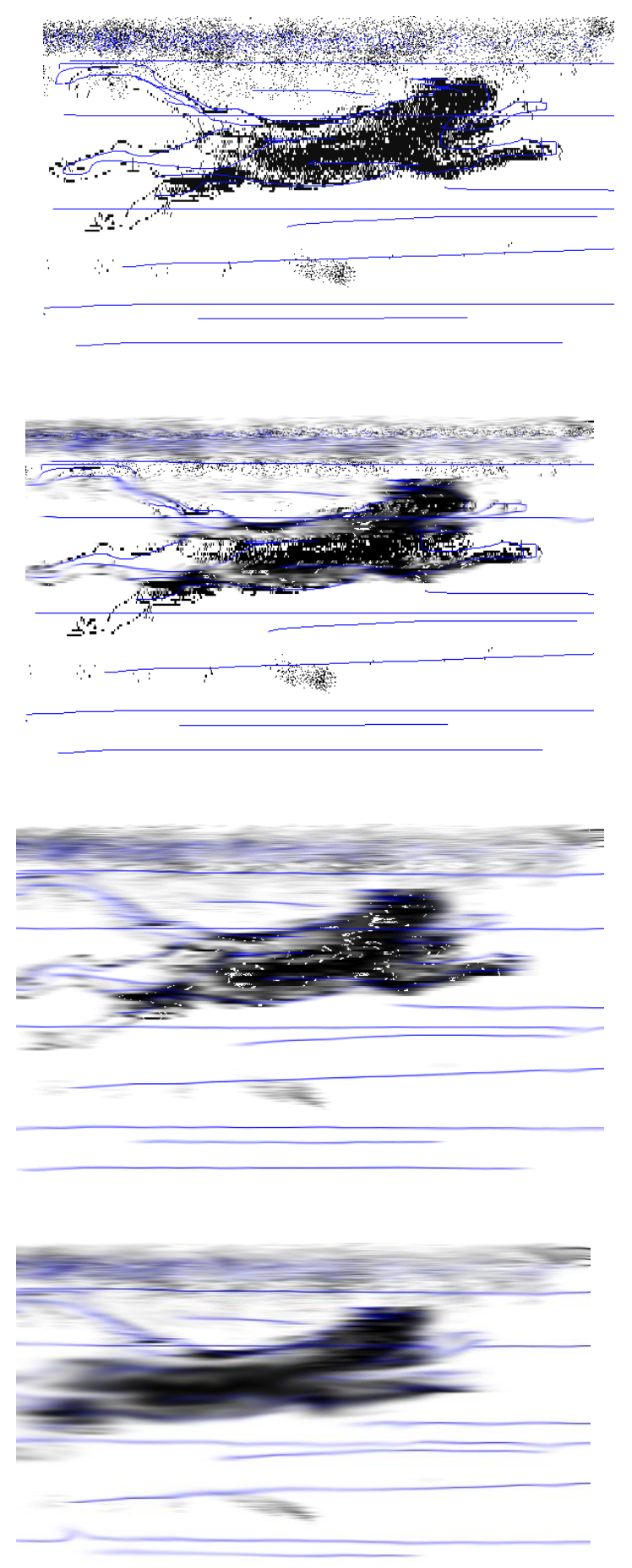
A Seqüência 1: Fuga se compõe na verdade de um único desenho que foi repetidamente borrado da direita para a esquerda (com ferramenta do programa Adobe Photo de Luxe), em etapas que foram gravadas separadamente. Tivemos então, a sensação de que a figura, representada em movimento, parece realmente se deslocar com velocidade e quando as etapas foram colocadas em sequência, no programa Macromedia Flash, presenciamos o resultado fluindo organicamente como se as etapas não houvessem sido executadas - como num filme básico de animação. Porém, o que me chamou a atenção foi que as metamorfoses da imagem parada (representando a figura em movimento) revelavam uma possibilidade de representar o movimento aparente da figura sem que houvesse um deslocamento no espaço, essa atenção iria dar subsídios para a produção subseqüente - os desenhos com fuligem de fumaça a partir do ano de 2007 - e despertar nos anos seguintes minha admiração pela obra de Muybridge.

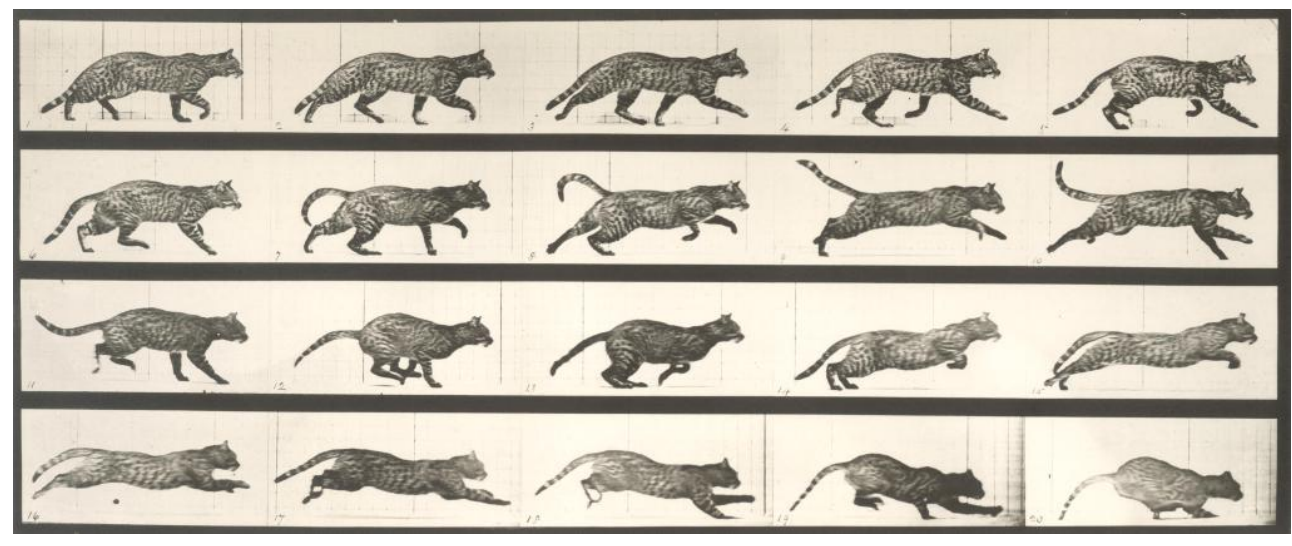

Muybridge. Attitudes of Animals in Motion. Sequência Fotográfica. c. 1880.

Diferentemente, a pesquisa de Marey visou o deslocamento do corpo no espaço.

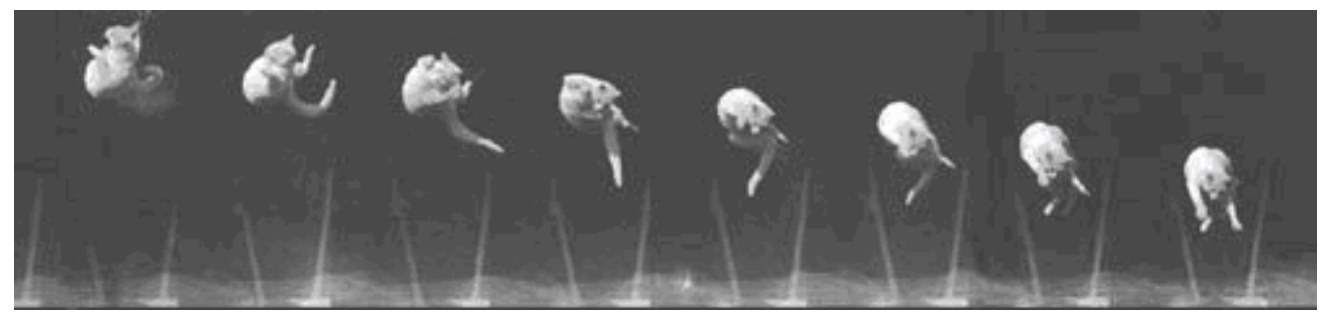

Marey. Estudo da Queda de um Gato. Fotografia (Cronofotografia), c. 1880.

Outro aspecto que me chamou a atenção, além da luminosidade da cor, foi a intensidade que as formas adquiriram quando projetadas, o que me instigou a realizar algumas aquarelas sobre papel para tentar atingir aquela intensidade luminosa: o resultado foi bastante frustrante. Não consegui alcançar uma relação similar em pigmento para a cor-luz numa pintura sobre papel. Pois não havia cores justapostas que causassem conflito e que por sua vez, quem sabe, gerariam a intensidade cromática. Na pintura, a figura se apresentava isolada, opaca e monocromática. 


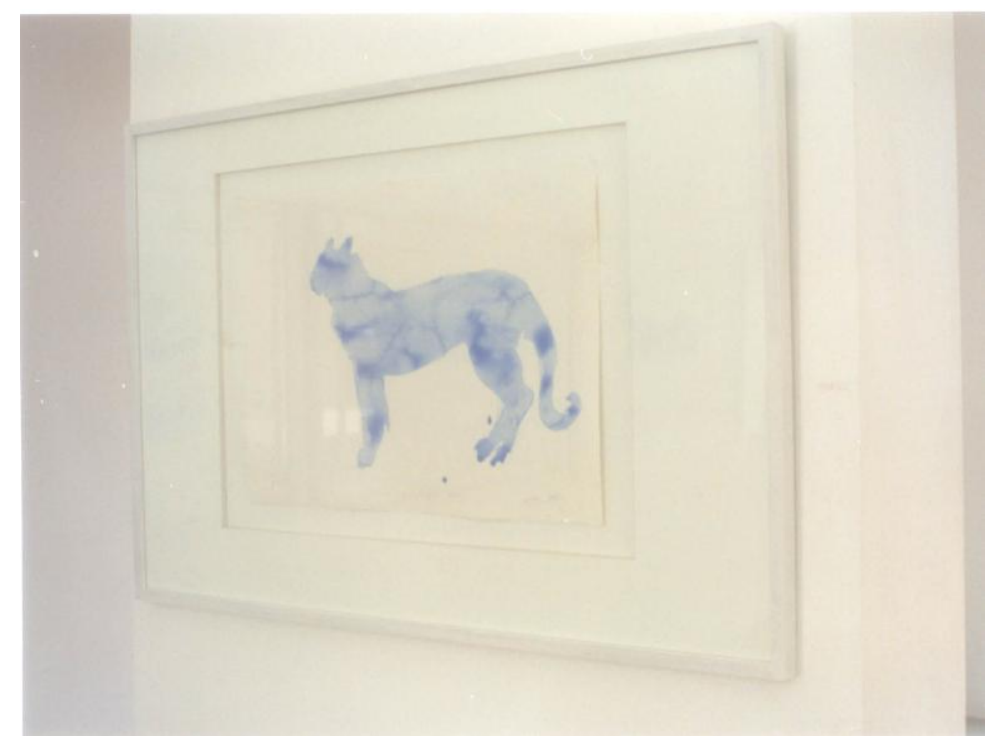

Eclipse. Aquarela sobre papel

Arches, 50 x $70 \mathrm{~cm}$. Araçatuba - SP, 2000.

Desinteressei-me das relações cromáticas com pigmento. Além de, sempre ter tido muita dificuldade em resolver os problemas de cor que a linguagem da pintura exige, esse desafio iria acabar me conduzindo para outro caminho ainda mais complexo do que havia me proposto. Apesar de não ter ficado satisfeito com os resultados cromáticos, obtive uma nova apreciação da pintura em aquarela: observando essas aquarelas muito aguadas de perto, percebi que não havia pintado sobre o papel, mas que a tinta havia penetrado no suporte por causa da absorção do papel Arches, e que o desenho não se encontrava mais na superfície: a figura do felino estava dentro do suporte, havia sido absorvida sem formar uma película. A figura se encontrava internalizada no papel. Novamente a questão do espaço reaparecia, agora na forma de camadas de tinta entranhadas no papel.

Como buscava um formato cada vez maior, em decorrência das projeções virtuais, e como queria uma obra sem moldura e vidro, comecei a executar algumas pinturas com tinta acrílica com a mesma intenção de colocar a figura entre camadas de veladuras dando a impressão de que ela não se localizava apenas sobre a tela. No entanto, como a tela não possuía o mesmo poder de absorção do papel, foram necessárias várias camadas de tinta muito translúcidas, bem ralas de pigmento, para sugerir que a figura estava entremeada. A fim de conseguir se assemelhar às características da linguagem da aquarela, havia a necessidade de colocar maior número de veladuras, chegando a mais de cinco dezenas para cada quadro. O serviço se estendeu por meses por causa da secagem lenta das demãos muito aguadas de tinta acrílica que criavam possas. Para tentar fazer com que a figura ao invés de se projetar, recuasse para o interior da tela, era necessário tingir ao invés de apenas pintar. 
Manhã I. Tinta acrílica sobre tela: $116 \mathrm{~cm}$. x $144 \mathrm{~cm}$. Araçatuba - SP, 2005.

Durante esse período - 2005 - cheguei a realizar vários experimentos com outros materiais no intuito sempre de internalizar a figura. De modo mais óbvio e imediato, cheguei a entremear a figura desenhada com carvão entre as telas de gaze num suporte de madeira, tendo o cuidado de fazer com que a trama do tecido obedecesse às curvaturas lineares da figura. 


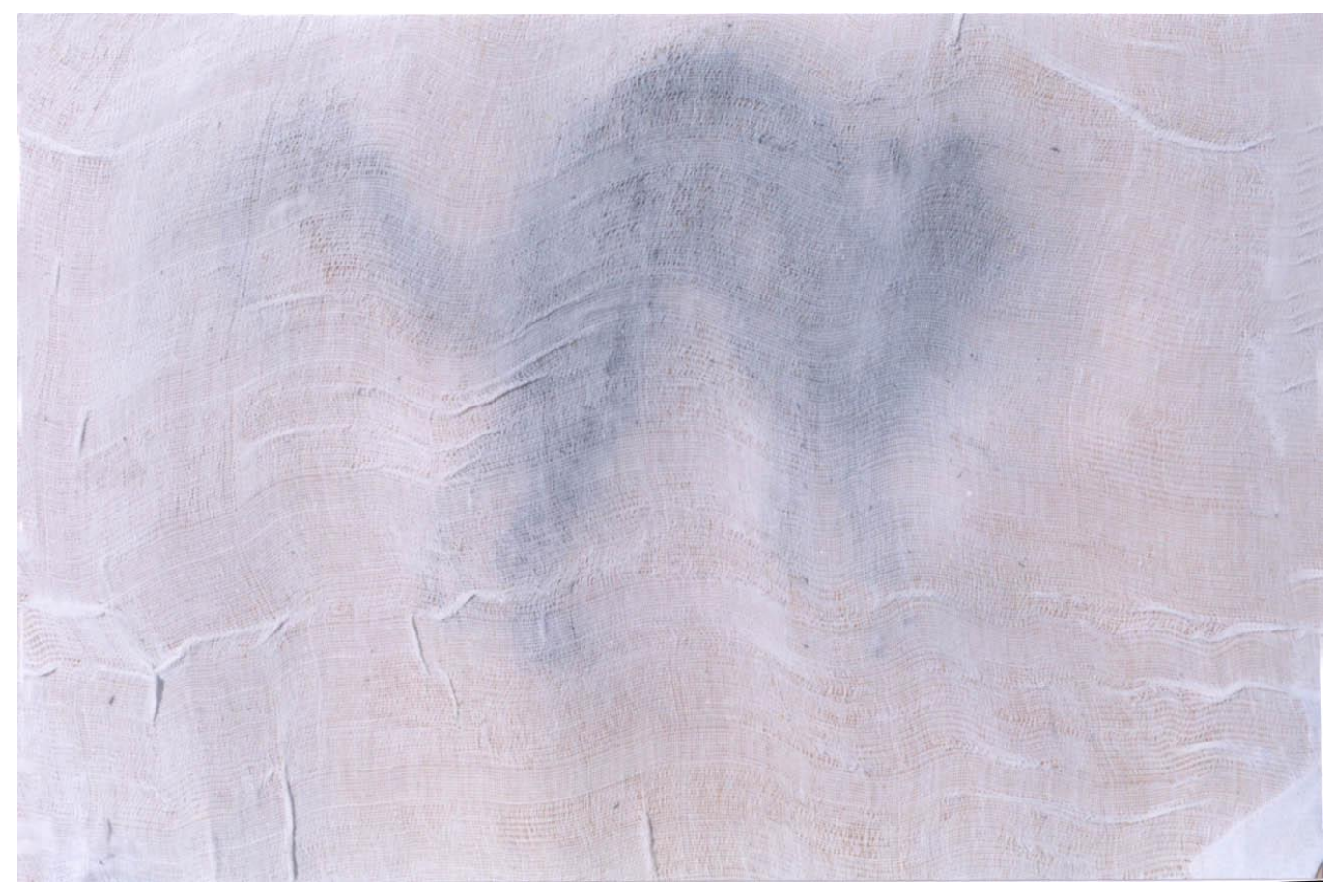

Manhã. Gaze colada com gelatina sobre desenho a carvão, sobre compensado de madeira. $35 \mathrm{~cm}$ x $50 \mathrm{~cm}$. Campinas - SP, 2005.

A pesquisa técnica prosseguiu com o uso da parafina derretida, sempre procurando um lugar que permanecesse a figura entre a superfície da obra e o fundo. Num processo técnico um pouco complicado, porém muito utilizado em artesanato: a figura era pintada com betume sobre papel pardo, que depois era encolado com uma camada translúcida de verniz acrílico. Depois da secagem do verniz, o papel era deixado de molho em água durante dias para se desfazer. Como resultado, o desenho se transferia do papel para a capa de verniz transparente, tornando-se uma película que mais tarde era colocada entre as camadas de parafina quente aplicada com pincel sobre chapas de compensado de madeira. Uma imagem embaçada passou a ser entrevista em meio de parafina. Como as camadas de parafina são muito quebradiças, o suporte de tecido foi substituído por superfícies mais rijas.

Achei que o suporte opaco impedia maiores lances de profundidade no espaço por transparência, portanto passei a utilizar o vidro, parafina sob vidro. A obra passou a requisitar qualidades de uma visibilidade dificultosa, que achei interessante, e o vidro permitiu entrever o fundo mais distante a $5 \mathrm{~cm}$. - da madeira. 


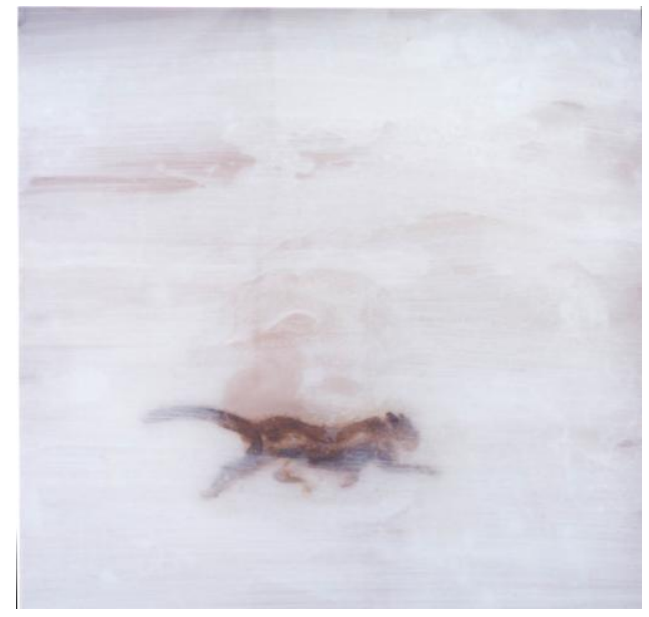

26 x $27 \mathrm{~cm}$. Araçatuba - SP, 2005.

Chuva - Parafina I. Parafina sobre recorte sob vidro

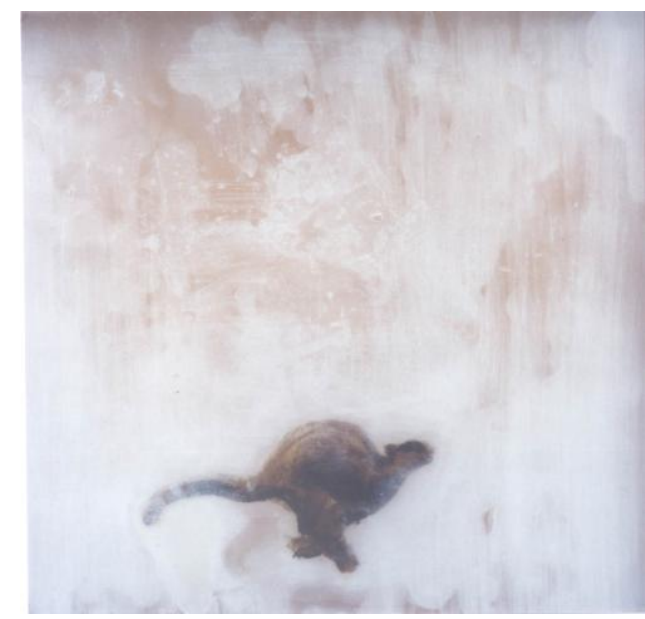

26 x $27 \mathrm{~cm}$. Araçatuba - SP, 2005.

Chuva - Parafina II. Parafina sobre recorte sob vidro

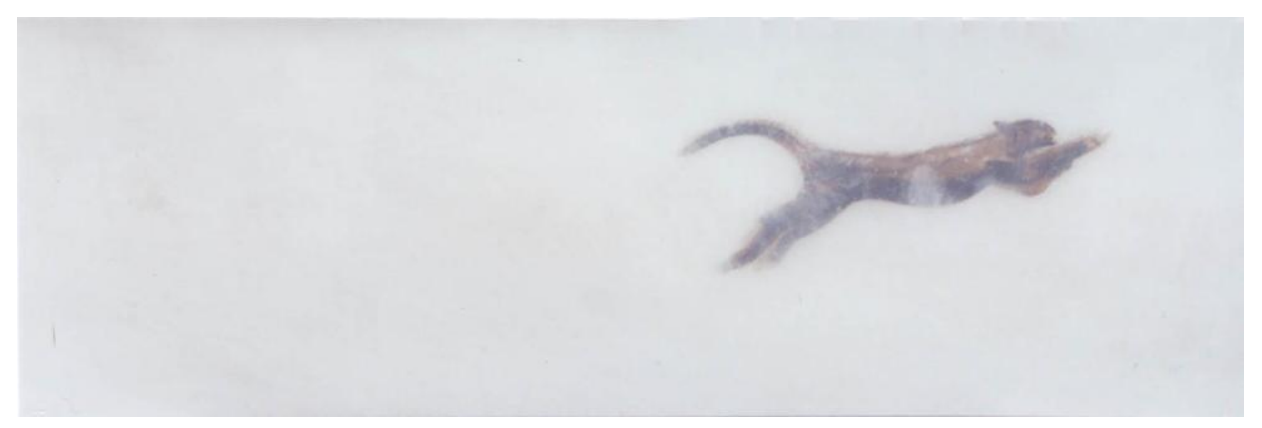

Chuva- Parafina III. Parafina sobre recorte sob vidro 60 x $21 \mathrm{~cm}$. Araçatuba - SP, 2005.

$\mathrm{Na}$ altura desse processo, notei que durante todo o tempo estava tentando operar com a transposição entre procedimentos da linguagem pictórica. Esforçando- 
me para transpor o desenho digital no computador para a linguagem da aquarela, da aquarela para a pintura com acrílica, a da acrílica para a da colagem. Porém, sempre tendo em mente $\mathrm{o}$ fato de que o suporte não me apresentava sob a forma bidimensional.

Concluindo essa trajetória - desenhos digitais - percebi que, independentemente da linguagem pictórica, eu estava procurando, de fato, o local de inserção da figura no espaço tridimensional percebido enquanto camadas translúcidas sobrepostas - cujo domínio me era bastante familiar na escultura.

A figura estava sendo empurrada para dentro do corpo da pintura, estava afundando e sendo posicionada entre camadas de matéria diluída, eu compreendia a linguagem pictórica com o aspecto de avanços e recuos materiais.

E, mais tarde, em decorrência disso, viriam os desenhos com fuligem de fumaça e as esculturas de fuligem de fumaça propriamente ditas, onde o lugar da figura continuaria a ser reposicionado.

\section{Trabalhos da década de 1980: O FUNDO E A FIGURA}

Geralmente o processo da pintura ainda me é bastante dificultoso até hoje. Além do problema das relações das cores, existe o da colocação dos planos mais recuados, do fundo da pintura. Raras vezes consegui "encaixar" um fundo para as figuras já finalizadas. Geralmente eles entravam em conflito. Isso levou à destruição de várias telas. Problema de representação que não ocorre na escultura, uma vez que o fundo é o próprio espaço do ambiente.

No meu caso, mesmo no desenho sobre papel a representação do espaço em torno da figura é complicada, porque parece que o fundo tem de ser preenchido de modo a integrar a figura. É frustrante estabelecer essas relações porque geralmente um acaba estragando o outro.

Isso me levou há alguns anos a utilizar a solução recorrente e imediata de recortar as figuras dos desenhos e das pinturas conflituosas prontas, eliminando o fundo.

Assim surgiu a série dos "Recortes":

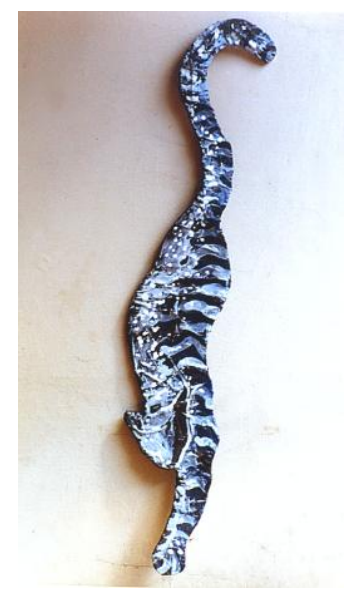

Recorte de folha de Flandres, tecido e encáustica, 110 cm alt. Araçatuba -SP, 1985. 


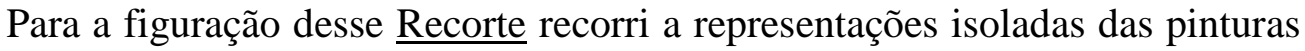
de artistas consagrados.

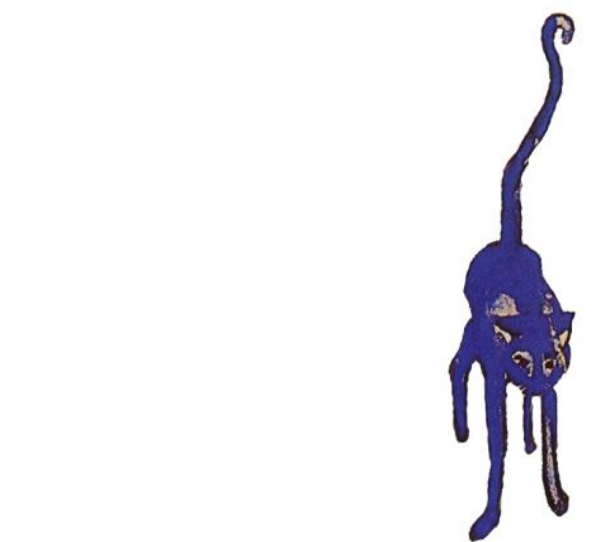

Franz Marc. As Três Panteras do Rei Yussuf. 1913.

Tinta, aquarela, guache: 13,8 × $9 \mathrm{~cm}$. Munique, Bayerische Staatsgemäldesammlungen. Detalhe.

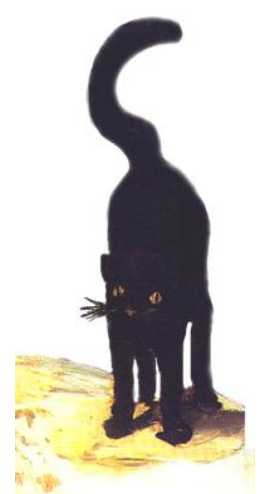

Manet. Olimpia. 130 x 189 cm.1863. D'Orsay Detalhe.

O desenho da figura prescindiu da moldura e da construção de um entorno na parede. Parece que a figura passou a compartilhar do nosso mesmo espaço, o que já causou alguma estranheza. Porém isto ainda não foi satisfatório o suficiente. Parecia que estava fugindo do desafio de estabelecer uma relação harmoniosa entre o que era representado e o espaço da parede, o recorte pendurado ficava isolado, fechado nele mesmo.

Outra tentativa para colocar a figura bidimensional livre no espaço foi a colagem dos recortes de papel sobre lâminas de vidro transparente. Assim o fundo da pintura parecia se tomar a própria cor da parede onde o recorte era pendurado com moldura. Decidi desenhar e pintar diretamente sobre o vidro com lápis dermatográfico e com encáustica, entusiasmado com as pinturas sobre vidro de Klee. Utilizei a encáustica porque eu controlava o processo de confecção das tintas com matéria prima de boa qualidade e barata, além do que a secagem da pintura ocorria rapidamente - era só esfriar - e não utiliza produtos tóxicos. O processo se fazia pelo avesso, as primeiras camadas de cera quente depositadas sobre o vidro eram as primeiras a serem vistas pelo avesso - na pintura sobre tela, as últimas camadas sobrepostas de tinta é que são as primeiras a serem vistas.

Era necessário ter um senso bastante claro da ordem das camadas, uma seqüência a ser seguida, caso o resultado não ficasse bom era necessário escavar a cera para atingir a primeira camada e removê-la. No processo prático, muitos vidros se estilhaçavam com a alta temperatura da cera derretida. Porém, quando tudo corria bem, o trabalho alcançava uma transparência semelhante à linguagem da aquarela. E como o suporte era o vidro, o trabalho pronto lembrava um vitral.

Os trechos de pintura sem tinta deixavam transparecer o fundo, ou seja, a parede. No desenho sobre vidro com o lápis dermatográfico, apenas um ou outro traço no vidro límpido parecia deixar o desenho livre no espaço, tinha a impressão de que desenhava no ar, ou quando pendurado na parede ocorria a ilusão de que ele havia sido feito diretamente sobre a parede.

Tanto na pintura como no desenho havia a idéia de que eles devessem ser executados com menor número de correções possível para permitir uma ligeireza e 
espontaneidade do gesto de execução, mantendo certo frescor do fazer. De outro modo, o trabalho tinha um ar rançoso e cansado.

Sempre preocupado com a qualidade duradoura dos materiais artísticos, como a resistência dos pigmentos à luz, procurei obter um pigmento negro e muito fino, que não necessitasse ser moído. Surgiu a idéia de produzir o "negro de fumo", obtido a partir do resíduo da fuligem de combustão. Utilizando, então, uma lâmina lisa de vidro para colher a fuligem da chama de uma vela acesa, foi notado o rastro da trajetória trêmula da chama que havia sido registrado na superfície transparente.

Uma espécie de desenho construído com a fuligem, uma mancha feita ao acaso, apenas para depositar o pó, que vagamente lembrava a imagem de uma asa de uma mariposa. Vi, nessa experiência, relação com as anotações de Leonardo da Vinci, em que detinha a atenção sobre as manchas de musgo comuns nos muros da cidade, ou as nuvens no céu, uma configuração esboçada de um objeto que na verdade era projetada pela mente do observador.

Para construir uma mariposa inteira, a partir daquela mancha, foi fácil e o mais surpreendente: resultou num desenho com a qualidade volátil do inseto.

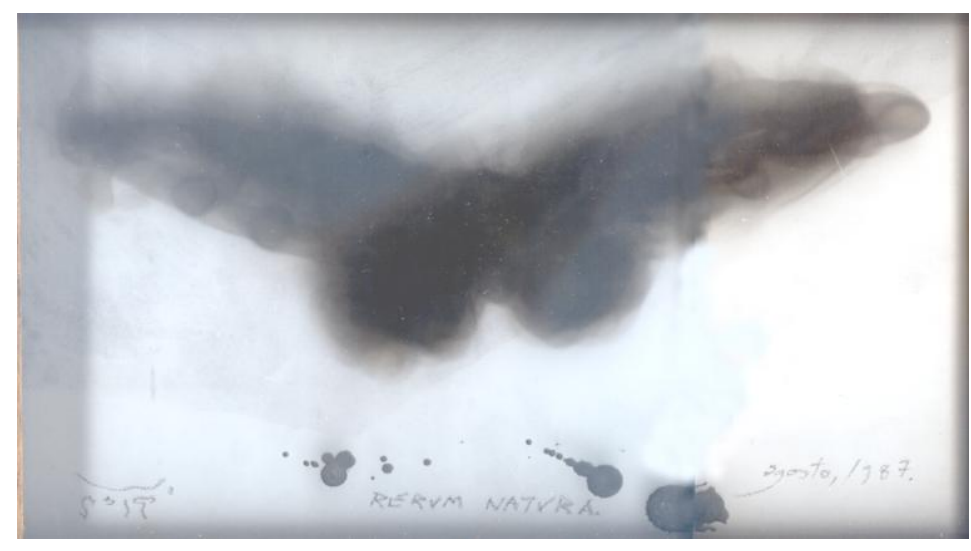

Mariposa 2. Fumaça sobre uma lâmina de vidro 3mm. 22 X $40 \mathrm{~cm}$. Araçatuba - SP, 1987.

Motivado pelos resultados dei início a uma série de desenhos com fumaça desenhando diretamente sob o vidro com a chama de uma vela. Finalizando com uma outra lâmina de vidro para proteger o desenho, a semelhança de um sanduíche lâmina, desenho, lâmina - e colando as bordas com adesivo sintético: uma cápsula. 


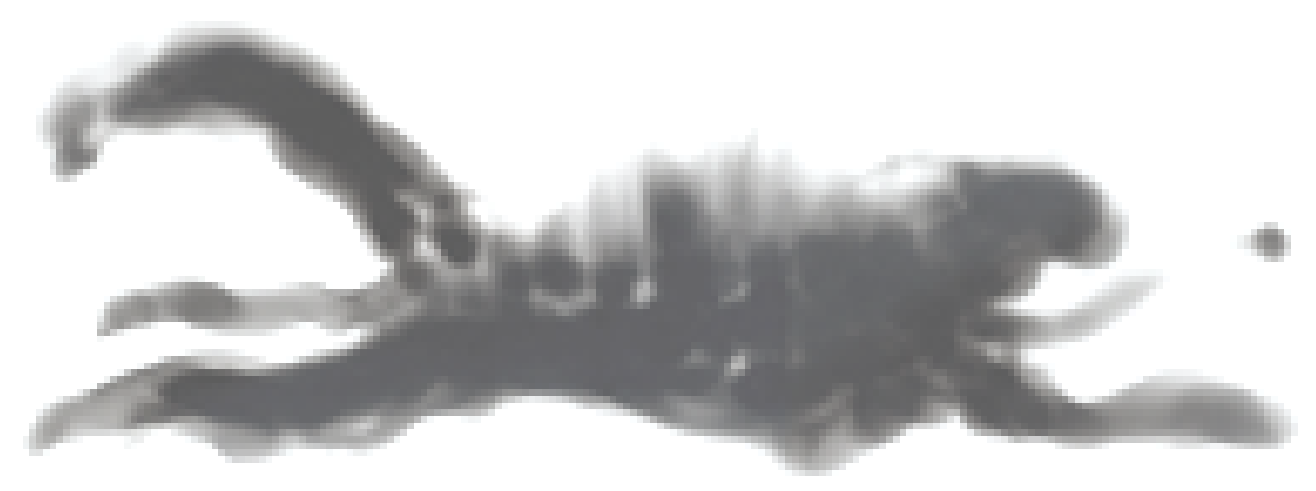

Fuga 8. Lâmina única de vidro 5mm. 30 x 50 cm. São Paulo - SP, 2006.

Nesse método de desenho evitei retoques, pois, creio que seja prejudicial para a espontaneidade do gesto direto, sem retoques me parece que emerge um frescor da execução e a captação fluída da matéria se torna mais natural. No entanto, é necessária uma destreza de execução, certa habilidade da mão para não perder a fluidez do lance de fumaça e manter a identificação da figura.

Ao emoldurar e pendurar esses desenhos eu notei que as manchas de fuligem diáfanas faziam sombra na parede dando uma sensação muito estranha de planos sobrepostos que, por sua vez, pareciam gerar volume, as manchas adquiriram uma enfática presença física e uma idéia embrionária de escultura. Um desenhoescultura.

Sobrepondo duas lâminas desenhadas, como no processo de execução das camadas de aquarela - veladuras - porém em vidros separados, era conseguido mais espaço em profundidade e uma percepção mais intensa do volume. O grão do pigmento da fumaça é tão fino que permite sutis gradações de transparência negra.

As placas de vidro funcionam como as páginas transparentes - folio - de um volumen que pode ser lido inteiramente estando ele ainda fechado.

Sem a necessidade de construir as relações da cor, nem o fundo e nem a representação da luz é possível conseguir resultados interessantes, ou seja, fazendo menos, a imagem parece ter adquir mais vitalidade.

Em 2007 descobri o seguinte depoimento de Duchamp no livro de Pierre Cabanne. Marcel Duchamp: Engenheiro do Tempo Perdido. Ed. Perspectiva :

"Quando você faz um quadro, mesmo abstrato, há sempre uma espécie de necessidade de preenchimento forçado. Eu me perguntava por quê"., pág. 27.

"-Como veio a idéia de utilizar o vidro?" - pergunta Cabanne a Duchamp. 
-Pela cor. Quando eu pintava, usava um grande e espesso vidro como palheta e, vendo as cores do outro lado, compreendi que havia qualquer coisa de interessante do ponto de vista da técnica pictórica.

A pintura ficava sempre suja, amarelada ou velha, ao cabo de muito pouco tempo, por causa da oxidação; agora, minhas cores se encontravam completamente protegidas, pois o vidro era um meio de mantê-las, ao mesmo tempo puras e livres de alterações por um bom tempo. Imediatamente apliquei esta idéia do vidro em A Noiva.

-O vidro não tinha uma outra significação?

-Não, não, nenhuma. O vidro, sendo transparente, podia dar o máximo de eficácia à rigidez da perspectiva; ele eliminou também toda a idéia de "mão", de matéria. Queria mudar, ter uma nova abordagem."

Pierre Cabanne entrevista Duchamp in Marcel Duchamp: Engenheiro do Tempo Perdido. Editora Perspectiva. págs. 69 e 70.

Passo. Obra que utiliza seis lâminas de vidro com fuligem de fumaça. $60 \mathrm{~cm} \mathrm{X} 80 \mathrm{~cm} \mathrm{X} 40 \mathrm{~cm}$ com base de madeira reciclada. São Paulo - SP, 2008. 


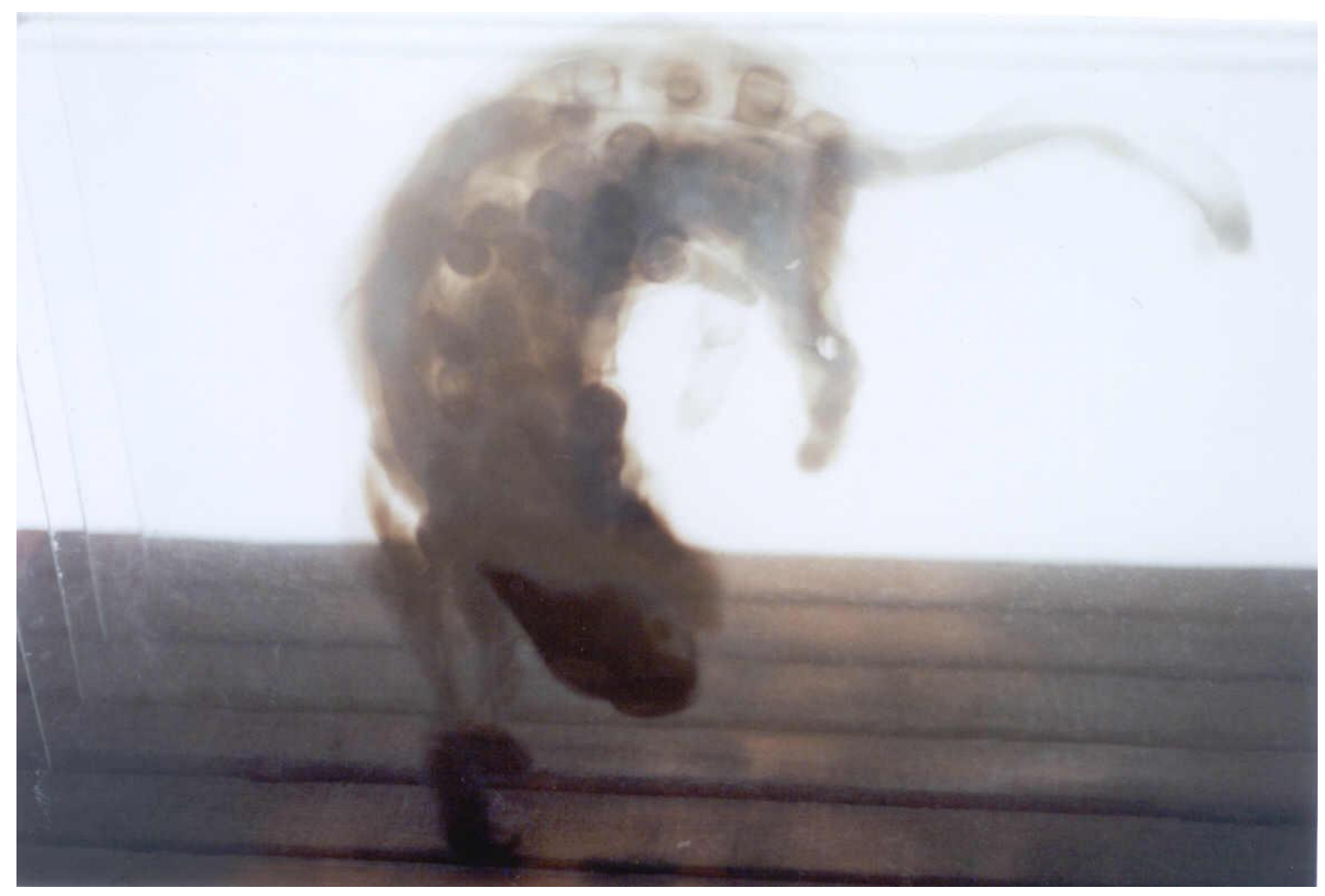

Passo. Detalhe.

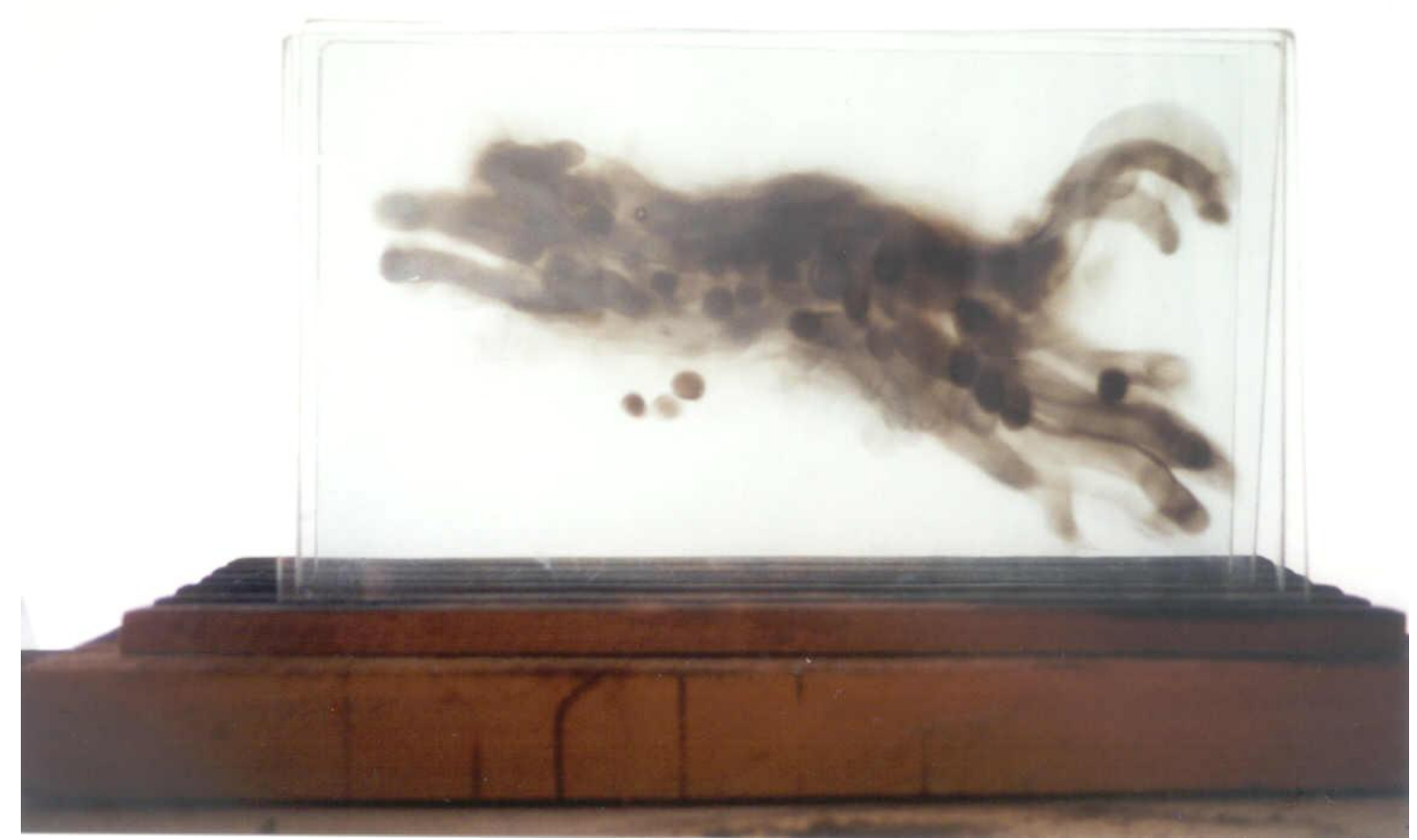

Salto 2. Obra que utiliza cinco lâminas de vidro com fuligem de fumaça. $60 \mathrm{~cm} \mathrm{X} 80 \mathrm{~cm} \mathrm{X} 40 \mathrm{~cm}$ com base de madeira reciclada. São Paulo - SP, 2007. 


\section{O VIDRO TEM COR:}

$\mathrm{O}$ vidro tem a característica de suporte para o desenho, substituiu a folha de papel opaca e permite deixar passar através por causa de sua transparência.

As placas sobrepostas de vidro como suporte inócuo, liso, plano, límpido e translúcido passa a ser um médium diáfano onde ocorre o volume.

Uma vez que o vidro idealmente devesse desaparecer deixando as camadas de fuligem livres no espaço, a quantidade de lâminas de vidro teve de ser limitada por causa da cor esverdeada do vidro comum. Quanto mais grossa a placa de vidro ou quanto maior o número de placas, menor é a visibilidade através delas, pois o vidro não permite cem por cento de transparência, daí ele vai se fazendo presente como uma massa esverdeada indesejada para este propósito.

Neste projeto, as dimensões, cerca de $250 \mathrm{~cm}$ x $350 \mathrm{~cm}$ para cada lâmina de vidro, cada lâmina tem a espessura de $1 \mathrm{~cm}$. Total: $8 \mathrm{~cm}$ de espessura de vidro.

Para que o espectador transite entre as placas de vidro, nos vãos de $90 \mathrm{~cm}$ e tenha uma sensação de estar envolvido numa paisagem de manchas construídas com a fumaça. $\mathrm{O}$ olhar a partir de dentro do vão limita a referência figurativa numa atmosfera mais rarefeita.. 


\section{A LUZ:}

Como a luz, na linguagem pictórica, pode ser conseguida a partir de uma relação de cores, na linguagem tridimensional, geralmente se trata de uma luz real, ou seja, não representada.

No caso da montagem da obra Fuligens, a luz externa do ambiente atravessa as lâminas de vidro e é modulada pelas transparências das camadas de fuligem. Essas camadas mais opacas vão impedindo e dosando a penetração da luz como um filtro no meio da obra.

Se a fonte de luz externa vier de uma única fonte, a quantidade de luz que consegue atravessar as lâminas continua iluminando o solo. Porém, a quantidade que fica retida no interior da série de lâminas projeta uma sombra da silhueta da figura.

Com essa sombra projetada no solo, a figura parece adquirir uma perturbadora consistência física. $\mathrm{O}$ animal parece adquirir um corpo mais compacto.

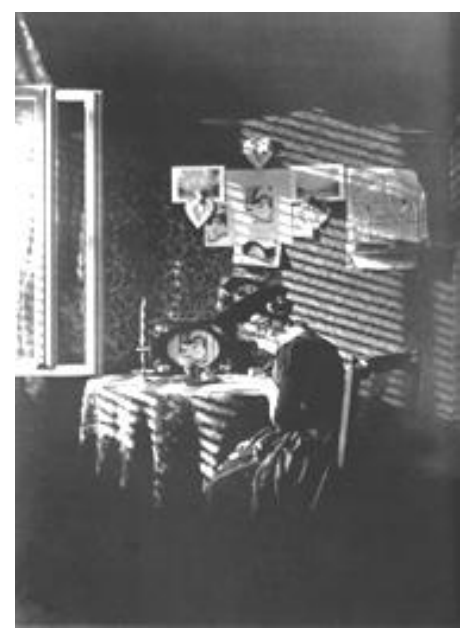

Alfred Stieglitz. Raios de Sol - Paula. Fotografia 22 x 16,2 cm. 1889

Na fotografia de Stieglitz o corpo opaco das venezianas impede a passagem da luz natural do exterior, à maneira de um filtro. Desse mesmo modo, as manchas de fuligem projetam sombras de intensidades diferentes desenhadas no chão.

\section{O PROCESSO DE EXECUÇÃO:}

No processo de execução da figura, cada placa de vidro é colocada na posição horizontal e a chama do pavio - vela acesa - é conduzida por baixo da placa, deixando um rastro de fuligem. O procedimento para a construção das imagens é uma fonte de fogo em contato com o suporte sem envolver o toque da mão, um desenho pirotécnico. 
A fumaça tem uma consistência que adere facilmente ao suporte - o vidro como um pigmento negro que prescinde do aglutinante. $\mathrm{O}$ resultado visualmente recorda o sfumato da pintura: modular como se fosse com fumaça.

À semelhança da sombra, a fuligem depositada remete à penumbra cada vez mais escura representada no desenho, equivalendo a maiores profundidades em gradações mais sutis. Essas sombras (camadas de fuligem), por sua vez, quando iluminadas com hofotes, produzem sombras reais no chão e nas paredes do ambiente: o que é desconcertante, pois lembram muito as sombras reais projetadas por uma figura muito mais sólida (massa), como se ela estivesse fisicamente presente.

A fuligem negra é, na verdade, um pigmento permanente - não desbota quando exposta por muito tempo à luz do Sol - porém é bastante frágil ao toque. Possui uma qualidade perene e, ao mesmo tempo, frágil.

As fuligens, quando vistas em duas ou mais lâminas de vidro sobrepostas, procuram ocupar o espaço em três dimensões como é a característica de inflar natural da fumaça. O desenho plano, então, parece se expandir fisicamente, adquirindo assim outras dimensões.

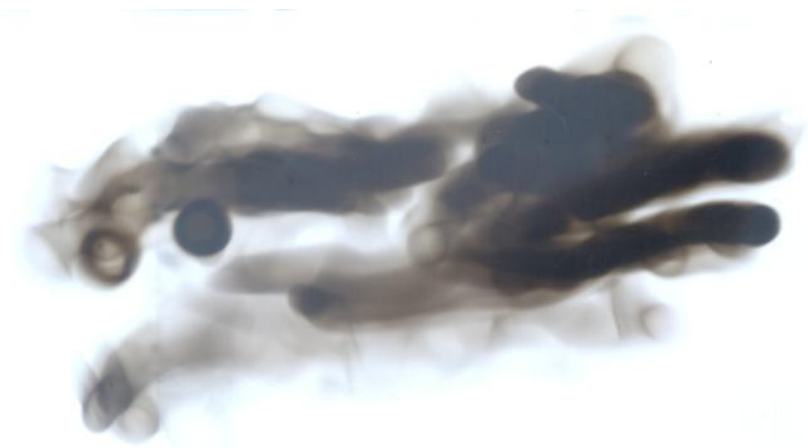

Uma das lâminas de vidro com fuligem de fumaça 30 X $50 \mathrm{~cm} .2006$

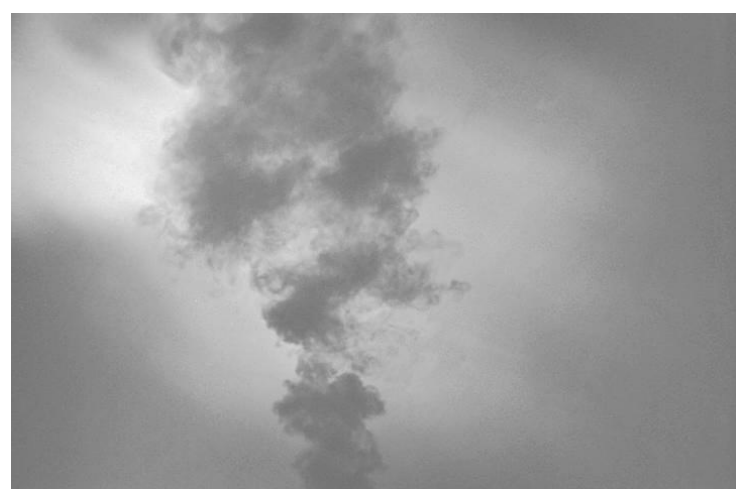

1941.

Orson Welles. Fotograma do filme Cidadão Kane, 


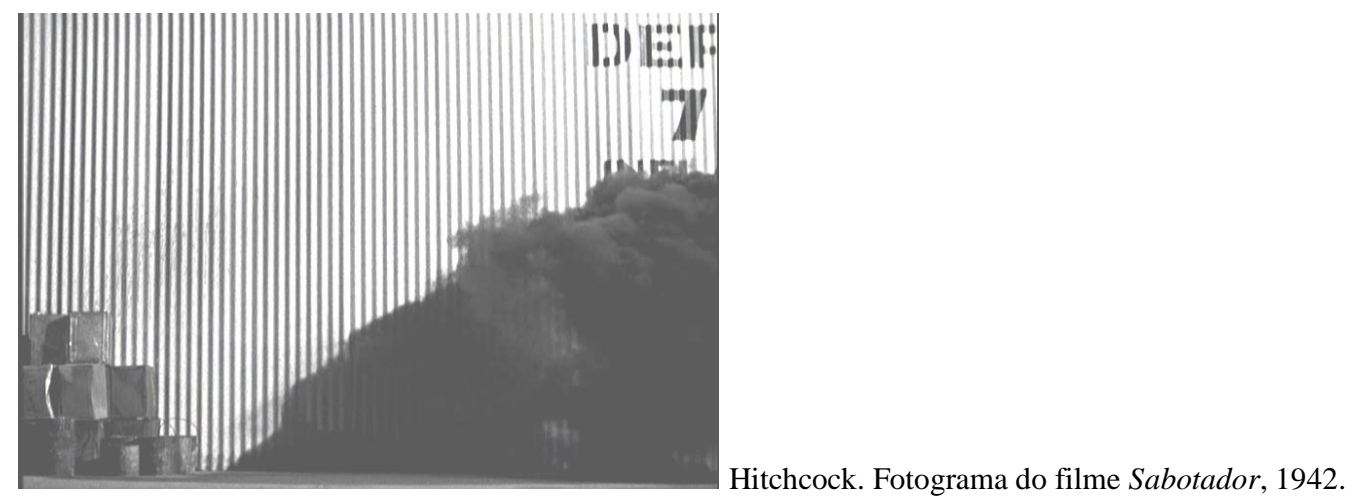

\section{A ESCULTURA:}

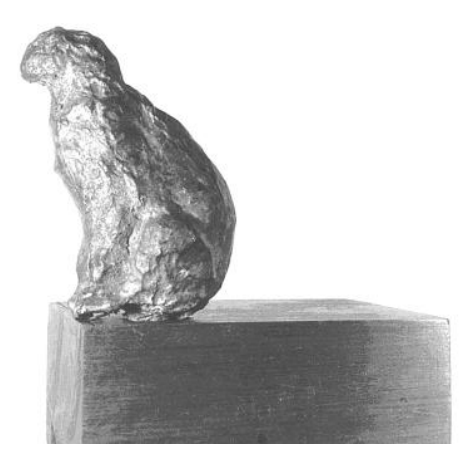

Atalaia. Chumbo e madeira, $32 \mathrm{~cm} \mathrm{X} 27 \mathrm{~cm} \mathrm{X} 35$ cm. São Paulo - SP, 1984.

Creio que a escultura leva em conta a idéia da existência de um lado seu que está sempre oculto dos olhos, mas que está sempre presente. Ele pode não ser visto, mas pode ser percebido. Mesmo executada com matéria transparente, pelo fato de considerar a escultura como uma obra que leva em conta, particularmente, um tempo maior na apreensão visual de seu todo, é natural que detenhamos nossa atenção num dos planos, e depois nos planos seguintes. E, a seguir, nos incita a reconstituir seu volume total mentalmente. Quando observada, uma escultura, naturalmente, abarca nossa atenção e não apenas os olhos.

E que a escultura permite infinitos perfis, contornos sempre em fuga, delimitando a superfície dela no espaço circundante. 


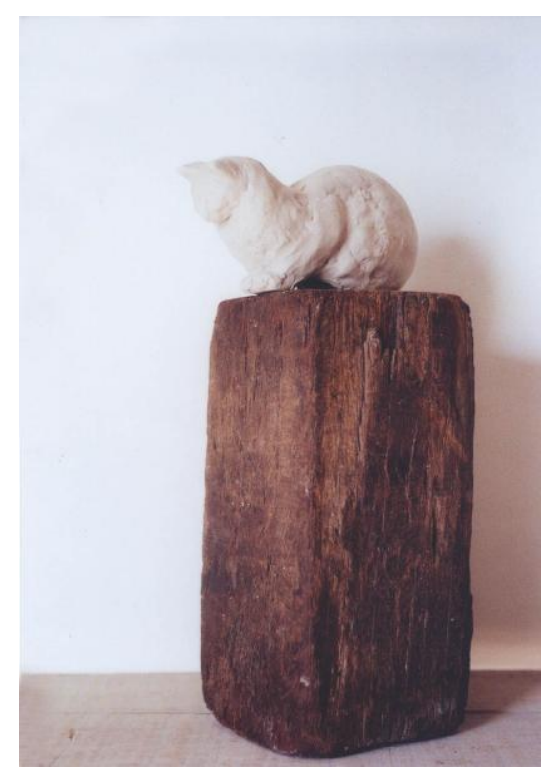

Atalaia. II. Terracota, base de madeira. $42 \mathrm{~cm} \mathrm{X} 21 \mathrm{~cm} \mathrm{X} 25 \mathrm{~cm}$. São Paulo - SP, 2009.

Ela pode ser entendida como uma expansão em três dimensões, a partir de um ponto, que atinge a justa medida para se impor como forma expressiva que invade o os limites do espaço envolvente em sua máxima plenitude.

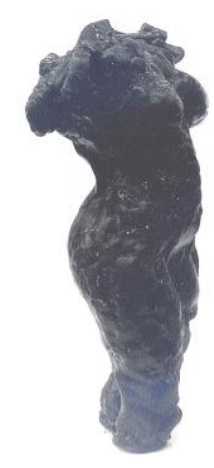

A Negra. Cera, 42 cm alt. São Paulo - SP, 1983.

O que me atrai especialmente na escultura é a sua óbvia e forte presença física, esse companheirismo que ela tem com os nossos corpos, fazendo com que passe assim a compartilhar conosco das intempéries. Atrai-me também uma indescritível qualidade silenciosa que ela parece possuir. Quando pronta, ela parece revelar uma determinada suspensão do tempo: tema caro nos mausoléus.

Neste projeto, seu volume aparece fatiado em lâminas planas de vidro e é depois, recomposto num segundo momento. 


\section{AS VISTAS SIMULTÂNEAS:}

Procurando operar com algumas lâminas de vidro colocadas umas sobre as outras tive a necessidade de marcar um registro à maneira da impressão de uma gravura que utiliza mais de uma matriz - como numa segunda cor a ser colocada. No princípio, procurei organizar as lâminas com a maior acuidade com relação a esse registro, pois a figura parada era construída seguindo uma precisão para dar a continuidade dos planos que formavam o volume. Mais tarde percebi que, se o registro não fosse seguido à risca, a imagem ficava "borrada" como se ela tivesse se deslocado no espaço.

A partir da consciência de que a noção do tempo poderia ser registrada ao deixar transparecer imagens simultâneas, procurei elaborar melhor o tempo e o espaço através da ligação de múltiplos planos que compõem a imagem, como os fotogramas sobrepostos de um filme.

O plano sobreposto e transparente do vidro permitiu a visibilidade do plano subjacente o que facilitou a demonstração dos princípios básicos de animação: um fotograma é exibido por um instante e depois é substituído por outro que mostra a mesma imagem com mínimas alterações, e por causa da persistência da imagem anterior na retina do observador ocorre a "fusão" de ambas as imagens revelando o registro do trajeto do movimento da figura: dois tempos simultaneamente mostrados. Só que, no meu caso, ao invés de registrar a figura na íntegra, foi colocado apenas um pedaço dela em cada lâmina, passando o tempo a ser segmentado junto com a forma: cada parte da figura se encontra registrada num tempo diferente. No entanto, o fotograma da imagem anterior não é excluído como no processo de animação.

Notei que ao registrar duas imagens em tempos diferentes - trechos da figura - as imagens se fundiam ao serem observadas, recompondo a forma inteira e, ao mesmo tempo, sugerindo que ela havia se deslocado no espaço. Como numa sequência cinematográfica.

Na observação de todas as lâminas sobrepostas nota-se o espaço em volume, pois a fuligem depositada sobre cada lâmina de vidro é dosada de modo a permitir a visibilidade parcial da lâmina que vem atrás.

Descobri algumas fotografias de Muybridge sobre o estudo do movimento dos animais - Attitudes of Animals in Motion -, e mais particularmente os felinos, que passei a utilizar como modelo para ter maior clareza da segmentação do movimento.

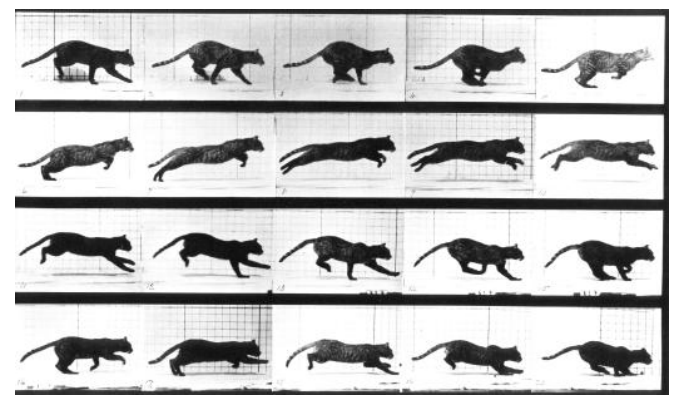

Muybridge. Attitudes of Animals in Motion. Vinte Fotografias tiradas por vinte câmeras posicionadas em intervalos regulares num corredor - espaço - e disparadas com intervalos regulares de tempo. c. 1880. 


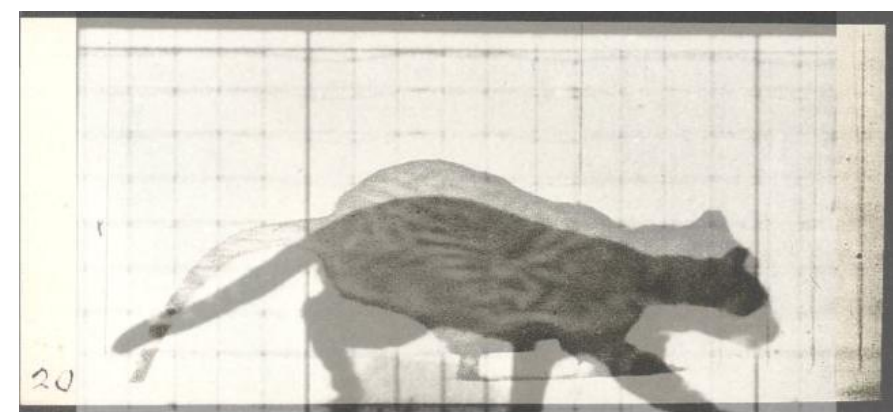

Muybridge. Attitudes of Animals in Motion. c. 1880. Dois fotogramas sobrepostos por transparência. Tempos diferentes expostos simultaneamente. Embora neste caso as imagens apareçam na íntegra, passei a utilizar diferentes fragmentos delas.

A possibilidade de representar a sequência do deslocamento da figura no espaço, utilizando superfícies estáticas, apresentou noções de tempo que me intrigaram.

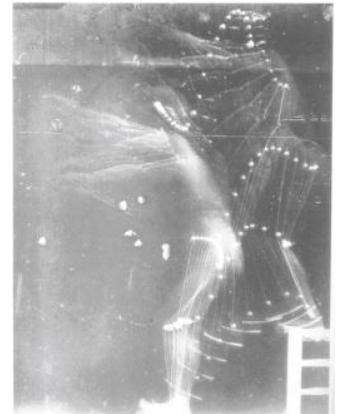

Marey, Análises do Pulo, das cronofotografias, 1884

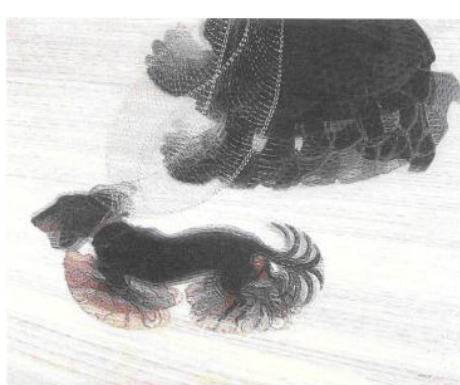

Giacomo Balla, Dinamismo de um Cão numa Trela. Óleo sobre tela 89,9 X 109,9 cm. MOMA-NY, 1912. 


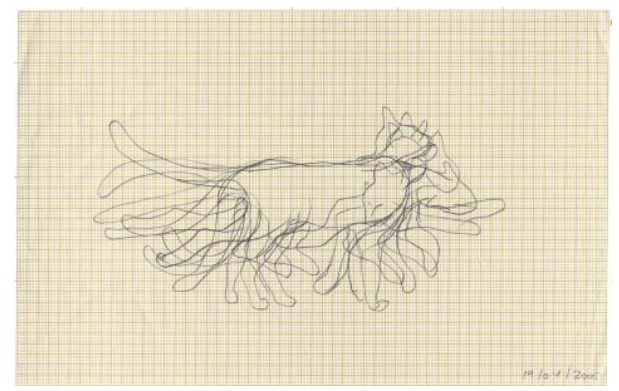

Estudo de 2005. Desenho a lápis sobre papel: $21 \times 30 \mathrm{~cm}$. Campinas - SP. Estudando a pintura de Balla, notei que as figuras parecem gesticular, mas não se deslocam horizontalmente no espaço.
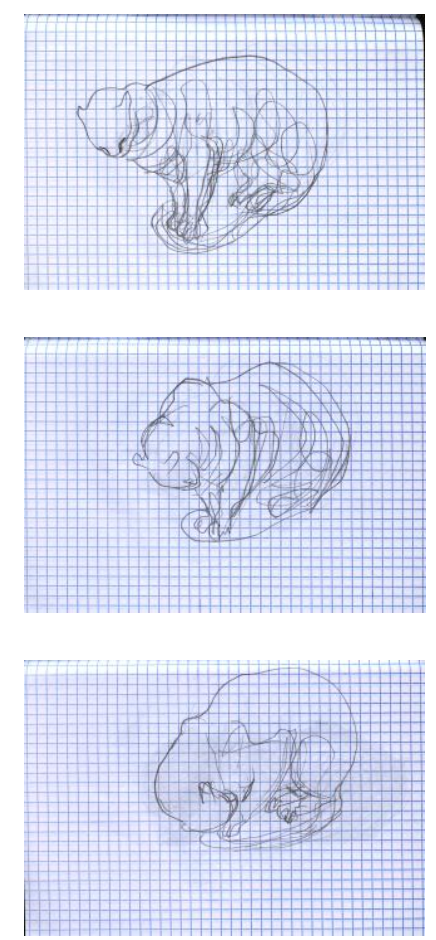

Sequência de animação. Páginas de um dos Cadernos do Trem: Luz-Guaianazes. Lápis 15 X 21 cm. 2007

As lâminas funcionam como registro de uma sequência do movimento da figura nas suas respectivas mudanças de posição. E que passam a ser vistas simultaneamente devido às qualidades transparentes do vidro. Isso me permitiu operar com as qualidades de ritmo, que eu agora poderia acelerar ou retardar, explorarando controladamente as ênfases e os descansos na maneira de dispor as formas. 
Achei compreensível que os desenhos e as esculturas acompanhassem as dimensões de minhas pinturas mais recentes, portanto comecei a trabalhar com placas de vidro cada vez maiores e procurei imaginar o quanto seria interessante a possibilidade de obter, com sucesso, uma visão a partir do interior da obra, daí surgiu a idéia de montar instalações.

Acredito que, como obra de grande formato - 2,20 x 3,50 x 3,20 metros - ela acaba relacionando e envolvendo do corpo do espectador, permitindo uma leitura a distância, de fora da obra, e outra, bastante próxima, a partir de dentro dela. O que possibilitaria uma nova experiência da obra.

\section{CONCLUSÃO:}

Até o momento, averiguando o processo e concepção deste projeto, notei que, no período do mestrado, a necessidade de esclarecer explicita e objetivamente os mecanismos desse processo e dessa concepção trouxe indagações que de outro modo não seriam notadas no trânsito produtivo, e que se fazem necessárias para a administração da poética - produção.

A fonte reflexiva sobre este projeto se originou no fazer artístico, e acrescentou-lhe novas perspectivas enquanto o desenho permaneceu valorizado como base de concreção para as idéias - designo.

A convergência das duas linhas de pesquisa anteriores - a produção da década de 1980 e os desenhos digitais - produziu uma série de obras que possui desdobramentos mais complexos.

Ao procurar materiais de qualidades mais perenes para manter a obra fisicamente mais duradoura, elas foram encontradas, contraditoriamente, nos materiais fisicamente mais frágeis: fuligem e vidro. A fuligem de fumaça foi materialmente utilizada como origem e medium nesse processo de construção. A eleição dos materiais utilizados - fumaça e vidro - os transformou em meios insubstituíveis pelas características de sua matéria.

A obra é ostensivamente figurativa, e monotemática: animalista - donde veio minha admiração pela obra do escultor Antoine-Louis Barye. Acredito que tendo repetido o tema por mais de vinte anos, fez com que ele me liberasse, para me deter em outras preocupações. 

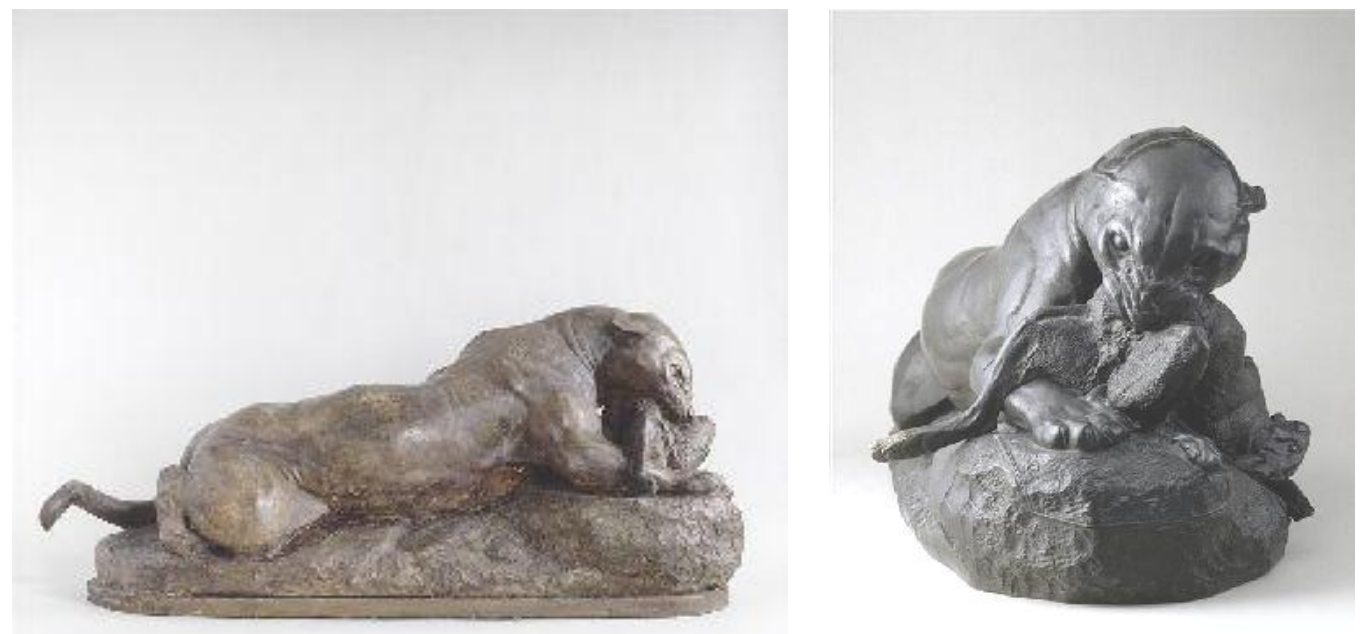

Barye. Jaguar Devorando uma Lebre. Bronze. 1855. Louvre, Paris.

Não houve uma preocupação em limitar a definição da obra quanto à sua categoria de instalação, ou de escultura ou de desenho. De outro modo, a obra se propõe como um ente "misto", em que as especificidades das linguagens tornaram-se secundárias diante das necessidades vigoradas durante o processo de elaboração da obra.

O interesse em concretizar a obra surgiu de questionamentos gerados no interior dela, sempre balizados numa clara postura da tradição figurativa.

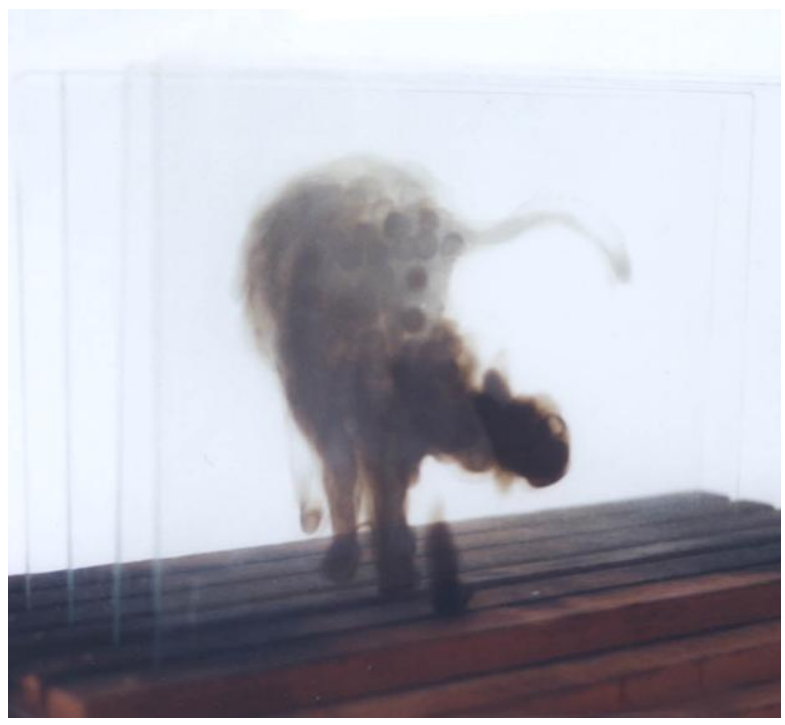


BIBLIOGRAFIA UTILIZADA NO MESTRADO:

ADORNO, Theodor W. La Critica de la Cultura y La Sociedad - Museo ValéryProust. Ariel, Barcelona; 1962.

ARNOLD, Mathias. Toulouse-Lautrec - The Theatre of Life. Taschen, Colônia, Alemanha; 1987.

BACHELARD, Gaston. A Poética do Espaço. Os Pensadores, Nova Cultural São Paulo; 1988.

BACHELARD, Gaston. O Novo Espírito Científico. Os Pensadores, Nova Cultural São Paulo; 1988.

BAILEY, Martin. Dürer. Phaidon Press Limited, Londres; 1995.

BELluZZO, Ana Maria de Moraes. O Brasil dos Viajantes. Fundação Odebrecht Objetiva, Rio de Janeiro, RJ e Metalivros, São Paulo; 2000

BENJAMIN, Walter. Obras Escolhidas. Brasiliense, São Paulo; 1987.

BERGGRUEN, Oliver e HOLLEIN, Max. Henri Matisse - Drawings with Scissors. Prestel; 1990.

BORGES, Jorge Luis. Cinco Visões Pessoais. Universidade de Brasília, Brasília; 1985.

BOULEZ, Pierre. Le Pays Fertille - Paul Klee. Gallimard, Paris; 1989.

BURROUGHS, William. O Gato Por Dentro. L\&PM. Porto Alegre; 1992.

CLARK, T. J. Modernismos: Ensaios sobre Política, História e Teoria da Arte. Salzstein, Sônia: Organização. Cosac \& Naify, São Paulo; 2007.

CHIPP, H.B. Teorias da Arte Moderna. Martins Fontes, São Paulo; 1999.

DELEUZE, Gilles. A Imagem-Tempo. Brasiliense, São Paulo; 2007.

DERRIDA, Jacques. Torres de Babel. UFMG, Belo Horizonte; 2002.

FELBINGER, Udo. Henri de Toulouse-Lautrec. Könemann, Colônia, Alemanha; 1999.

FRIEDLANDER, Walter. De David a Delacroix. Cosac \& Naify, São Paulo; 2001.

GENET, Jean. O Ateliê de Giacometti. Cosac Naify, São Paulo; 2000. 
GILLOT, Françoise. Matisse e Picasso. Siciliano, São Paulo; 1992.

GIRARD, Xavier. Matisse - The Sensuality of Colour. Thames and Hudson, Londres; 1993.

GREENBERG, Clement. Arte e Cultura. Ática, São Paulo; 1996.

GROHMANN, Will. Klee. Abrams, NY; 1985.

HALL, James. Dictionary os Subjects \& Symbols in Art. Icon Editions, NY; 1980.

HIBBARD, Howard. Masterpieces of Western Sculpture. Thames and Hudson, Londres; 1977.

HUMPHREYS, Richard. Futurismo. Cosac \& Naify, São Paulo; 1999.

JEFFREY, Ian. The Photography Book. Phaidon Press Limited, Londres; 1999.

KLEE, Paul. Diários. Martins Fontes, São Paulo; 1990.

KLIBANSKY, Raymond, PANOFSKY, Erwin , SAXL, Fritz. Saturno y a Melancolía - Estudios de historia de la filosofia de la naturaleza, la religión y el arte. Editora Alianza Editorial S.A., Madri, Espanha; 1991.

KRAUSS, Rosalind. Caminhos da Escultura Moderna. Martins Fontes, São Paulo; 1998.

LACHENAL, François. 100 Anos de Arte na Alemanha 1885-1985. Giese-Druck, Offenbach, Alemanha; 1985.

MATISSE, Henri. Escritos e Reflexões Sobre Arte. Ulissea, Povoa de Varzin, Portugal; 1972.

NAUBERT-RISER, Constance. Klee. Estampa, Lisboa; 1988.

NÉRET, Gilles. EugèneDelacroix. Taschen, Colônia, Alemanha; 1999.

NÉRET, Gilles. Henri Matisse - Cut-Outs. Taschen, Colônia, Alemanha; 1994.

OLIVA, Achille Bonito. Trans-Avantgarde. Giancarlo Politi , Milão; 1982.

OLIVEIRA, Nicolas. Instalation Art. Smithsonian Institution Press. Thames And Hudson, Londres; 1994.

PANOFSKY, Erwin. Albrecht Dürer. Alianza Editorial, Madri; 1980.

PARTSCH, Susanna. Franz Marc. Taschen, Colônia, Alemanha; 2001. 
PARTSCH, Susanna. Paul Klee. Taschen, Colônia, Alemanha; 1993.

PEROSINO, Maria. Toulouse-Lautrec. Electa, Milano; 1992.

PIVAR, Stuart. The Barye Bronzes - A Catalogue Raisonné

RIBEIRO, Noemi. Oswaldo Goeldi: Mestre Visionário. Serviço Social da Indústria, São Paulo; 1996.

SCHMALENBACH, Werner. Catálogo da Mostra de Paul Klee no MASP; 1972.

SALZSTEIN, Sônia e ROELS Jr, Reynaldo: organizadores. $O$ Moderno $e \quad o$ Contemporâneo na Arte Brasileira, Coleção Gilberto Chateaubriand do MAM do Rio de Janeiro. São Paulo, Marca d'Água; 1998.

STRAUSS, Walter L. Albrecht Dürer - Intaglio, Prints, Engravings, Etchings and Drypoints. Kennedy Galleries, Inc., NY; 1975.

SELLIER, Marie. Barye - Des Mains Pour Créer. Paris Musées, Paris; 1987.

VERLAG, Herder. Dicionário dos Símbolos. - Herder Lexicon - Symbole. Círculo do Livro S.A., São Paulo; 1990.

WITTKOWER, Rudolf. A Escultura. Martins Fontes, São Paulo; 1989.

ZANINI, Walter. Tendências da Escultura Moderna. Cultrix, São Paulo; 1971.

Filmes:

WELLES, Orson. Cidadão Kane (Citizen Kane), 1941- RKO Pictures - Warner DVD, 1996.

HITCHCOCK, Alfred. Sabotador (Saboteur), 1942. Universal Studios DVD, 2002. 